\title{
A BitTer Pill to Swallow: PORTUGAL'S LESSONS FOR DRUG LAW REFORM IN NEW ZEALAND
}

\author{
Hugh McCaffrey*
}

\begin{abstract}
On 1 July 2001, Portugal decriminalised all drugs, replacing criminal sanctions with administrative ones. Portugal's decriminalisation policy focused on individual possession and use of drugs. It was thought that possession and use would be best dealt with outside of the criminal process. In New Zealand, the Law Commission is revisiting the Misuse of Drugs Act 1975. The author seeks to analyse the first two terms of reference: whether the legislative regime should reflect the principle of harm minimisation underpinning the National Drug Policy; and the most suitable model or models for the control of drugs. This paper examines the principles around the criminalisation of possession and use of drugs. In particular, it examines the experience of Portugal, some eight years after decriminalisation. It is argued that New Zealand should adopt a policy of harm minimisation and that the model Portugal presents ought to be seriously considered as a possibility for New Zealand reform.
\end{abstract}

\section{INTRODUCTION}

The Hon TM McGuigan, the then Minister of Health, in 1974 ironically stated regarding the introduction of the Drugs (Prevention of Misuse) Bill: ${ }^{1}$

I suggest that some countries have made mistakes in legislating on this matter, and experience has shown that their approaches to a vast social problem can have serious effects. I am confident that the Bill has avoided this pitfall.

Thirty-four years after the introduction of the Misuse of Drugs Act 1975 (MODA), it is clear that we have not avoided the same pitfalls that beleaguer other countries. ${ }^{2}$ Jurisprudential and

* Submitted as part of the LLB(Hons) programme at Victoria University of Wellington. I would like to thank my supervisor, Yvette Tinsley, for her invaluable help and support.

1 (18 July 1974) 392 NZPD at 3156.

2 Adrian Field, Sally Casswell Drug Use in New Zealand Comparison Surveys, 1990 \&1998 (Alcohol and Public Health Research Unit, Auckland University, 1999) at 39-45. See also Alcohol and Public Health 
medical thought is constantly adapting in light of new evidence that has been collected since 1975 . The MODA, however, has not.

On 1 July 2007, the Law Commission commenced a review of the MODA. ${ }^{3}$ The purpose of the ongoing review was to make proposals for a new legislative regime that will accord with New Zealand's international obligations and presumably reflect current empirical research and thought. ${ }^{4}$

The aim of this article is to examine the Law Commission's first two terms of reference: ${ }^{5}$

(a) Whether the legislative regime should reflect the principle of harm minimisation underpinning the National Drug Policy;

(b) What is the most suitable model or models for the control of drugs;

Drug policy is a complex matter. When considering reform, policy makers must examine a number of matters, including how best to control supply and manufacture. However, in the interests of brevity, this paper is limited to examining the appropriate response to possession and use of drugs.

The author will argue that the state response to the possession and use of drugs should not involve the criminal justice system for two main reasons. First, it will be argued that there is a principled reason to treat demand outside of a punitive system. To substantiate this point, principled criteria must be constructed, to determine when criminalisation should be utilised in society. Here, it is appropriate to consider the first of the Law Commission's terms of reference - examining whether harm minimisation is an appropriate policy goal. Constructing such criteria creates an ability to measure the appropriateness of the criminal process as a response to drug use and possession.

Second, it will be argued that there are other ways to achieve the objectives that lie behind the MODA. As an alternative model, the author will examine the experience of Portugal, which decriminalised the possession and use of all drugs on 1 July 2001, replacing criminal sanctions with administrative ones. ${ }^{6}$ This paper will analyse what the Portuguese model may be able to offer the present New Zealand review.

Research Unit Drug use in New Zealand: National Survey Comparisons 1998 \& 2001 (Alcohol and Public Health Research Unit, Auckland University, 2002) at $42<$ www.aphru.ac.nz>. All website sources were accurate at time of publication. See Appendix 1.

3 Misuse of Drugs Act 1975.

4 New Zealand Law Commission Misuse of Drugs Act Review Terms of Reference (Wellington, 2008) < www.lawcom.govt.nz>.

5 Ibid, at $[\mathrm{a}],[\mathrm{b}]$.

6 Mirjam van het Loo, Ineke van Beusekom and James Kahan "Decriminalisation of Drug Use in Portugal: The Development of a Policy" (2002) 582 The Annals of the American Academy of Political and Social Science 49 at 51. 


\section{THE HISTORY AND CONTEXT OF DRUGS IN NEW ZEALAND}

Before we can analyse the criteria of criminalisation, it is important to examine the rationales behind the passage of the MODA. This will help our understanding of what the legislative framework is trying to achieve.

\section{A History and Analysis}

The author will focus on the three most relevant rationales precipitating the introduction of the Drugs (Prevention of Misuse) Bill in 1974: ${ }^{7}$

\section{Cultural movement}

Leading up to 1975 there was a perceived cultural change. Policy makers were concerned that there was a greater acceptance and consumption of drugs: ${ }^{8}$

Overall the situation ... is not unlike that summed up in the lines of de Quincy about opium ... in 1822:

"Those who eat now who never ate before; and those who ate before eat now the more."

This was thought to be particularly true amongst the younger generation. ${ }^{9}$ It is not clear why drugs became more used during this period..$^{10}$ Many thought that the major cause was a rebellion against the 'establishment'. ${ }^{11} \mathrm{C}$ R Henwood chronicled this 'rebellion', choosing to do so through the words of Bob Dylan: ${ }^{12}$

Come mothers and fathers throughout the land

And do not criticise what you can't understand.

Your sons and your daughters are beyond your command,

Your old road is rapidly aging,

So get out of the new world if you can't lend a hand

For the times they are a'changing

\footnotetext{
7 Hon T M McGuigan, above n 1, at 3142. Board of Health Committee on Drug Dependency and Drug Abuse in New Zealand Second Report (NZ Board Hlth Rep Ser No 18, Wellington, 1973).

$8 \quad$ Ibid, at 19.

$9 \quad$ Ibid, at 96-97.

10 Ibid, at 9-23.

11 C R Henwood A Turned on World (Bond Print Limited, Wellington, 1971) at 15-16.

12 Ibid.
} 
There was, however, a counter-movement that lobbied for greater regulation. A sector of the public worried about unregulated therapeutic drugs in the wake of the thalidomide tragedy. ${ }^{13}$ Further, the medical community changed their view in relation to certain types of drugs. ${ }^{14}$ There was a growing conviction that the therapeutic value of amphetamines was limited, and that there was considerable scope for harm from use. ${ }^{15}$

\section{Punitive approach}

The most significant rationale behind the MODA was the continuance and consolidation of a punitive response to non-medical drug use. A punitive regime was implicitly accepted by the House as the best way to contain both the supply and consumption of drugs. ${ }^{16}$ Their conclusion relied on the Health Board's report: ${ }^{17}$

On balance ... the pontential [sic] for harm from the illegal, non-medical use of controlled drugs is great enough, especially in the case of ... central stimulants, and uncertain enough in the case of cannabis ...

to warrant retention of legal sanctions, as a last resort ... to contain the escalation of drug misuse ...

Four reasons became apparent from the debates in the House as to why consumption ought to remain illegal. ${ }^{18}$ First, the law should act as an educational mechanism. By making drugs illegal, society would be better informed of the harms that drugs 'inherently' cause. Second, there should be a deterrent effect. The stigma of being labelled an offender; or, the cost of sanctions placed upon the offender, should deter potential offenders from engaging in those activities. Third, society should be safer; fewer people would be exposed to the culture of drug taking that is 'inherently' harmful. Fourth, a retributive element; consuming drugs is inherently wrong, the law should punish those that engage in those acts.

\section{Treatment}

The final rationale was a focus on the need for greater treatment of addicts: ${ }^{19}$

Considered overall ... the attack on the problem of drug misuse in New Zealand has ... been ... directed at treating the symptoms and outward manifestations. This is understandable ... but it will prove

13 Board of Health Committee, above n 8, at 34.

14 Ibid, at 34

15 Ibid, at 36-37.

16 Hon T M McGuigan, above n 1, at 3142.

17 Board of Health Committee, above n 8, at 48.

18 J Harrison (9 October 1975) 402 NZPD at 5347.

19 Board of Health Committee, above n 8, at 37. 
increasingly inadequate unless as much or more attention is paid to research and action which attacks and, as far as possible eradicates the underlying causes.

This alternative focus was recognised by the Select Committee who saw the need for increased facilities for the prevention, treatment and rehabilitation of people misusing drugs. ${ }^{20}$ It seems that the House intended to adopt a dual approach where treatment came first and criminalisation came as a "last resort". ${ }^{21}$ Little time in the House, however, was devoted to alternatives to a criminal approach, such as rehabilitation and education.

Two additional rationales precipitated the MODA. First was the discombobulated nature of the legislative framework. ${ }^{22}$ Second, New Zealand needed to align its legislation with international obligations..$^{23}$ These, however, bear less relevance to the issues discussed in this paper.

Within this context, the newly named Misuse of Drugs Act came into force on 1 June 1977.24

\section{CRIMINALISATION}

The author will focus on the second rationale: that the best way to contain the growth in the use of drugs was, and still is, through the use of the criminal system. This is where there has been the greatest divergence in thought over the last thirty-four years. To be able to determine the applicability of this rationale it is vital to analyse the role of the State, and examine whether control is justified or warranted.

Society has a spectrum of responses that it can deploy when it believes harms flow from an activity. It is not clear when a state response is justified. State response often has little to do with the gravity or extent of harm inflicted. ${ }^{25}$ Of all the responses in the state's catalogue, criminalisation is

20 Drugs (Prevention of Misuse) Bill Committee 1975 [1975] IV AHJR I18 at 2-3.

21 Board of Health Committee, above n 8, at 48

22 Board of Health Committee on Drug Dependency and Drug Abuse in New Zealand First Report (1970). See also Hon T M McGuigan, above n 1, at 3142. The complex regime created confusion amongst those working in the area. Many new drugs fell outside the regulation of the Narcotics Act 1965, for example, the amphetamine group and barbiturate series fell, by regulation, under the Poisons Act 1960. The divide was arbitrary, but the consequences were real. Quantitative accounting for the storage of narcotics was needed, but not so for poisons and different rules surrounded prescriptions. This distinction seemed to favour newly developed psychotropic drugs.

23 C R Henwood, above n 12, at 61-62. It was recognised that without a global effort to combat drug trafficking the response of a single country would be fruitless. Between 1925 and 1953 international agreements and conventions widened the scope of control. This culminated in the 1961 Single Convention on Narcotic Drugs. This was an attempt by countries to "tidy up" the various conventions and treaties on illicit drugs.

24 Misuse of Drugs Act 1975, s 1(2).

25 Andrew Simester, GR Sullivan Criminal Law: Theory and Doctrine (3rd ed, Hart, Oxford, 2007) at 581. 
the most severe. It should be used "only when absolutely necessary". ${ }^{26}$ There needs to be clear social justification and a lack of alternatives. ${ }^{27}$ To judge the legitimacy of criminalisation, criteria need to be established. Simester and Sullivan provide generally accepted criteria that can be relied upon to set the ambit of criminal sanction. ${ }^{28}$ First, there must be a positive case for state regulation. ${ }^{29}$ To legitimise criminalisation there needs to be a significant level of harm suffered by others. ${ }^{30}$ If an activity reaches the threshold of harm suffered by others, then there seems to be a positive case. ${ }^{31}$ The second criterion must meet certain negative constraints: it must be shown that criminalisation is the best system to regulate the behaviour in question, compared to the alternatives. $^{32}$ Practicalities are integral to this criterion; the response must be "effective, enforceable, and meet rule of law and other concerns". ${ }^{33}$ Criminalisation should not be accepted if these negative requirements are not met, despite a clear positive case for criminalisation. ${ }^{34} \mathrm{~A}$ positive case for criminalisation is therefore a necessary, but not sufficient, criterion for criminalisation.

The multifarious nature of the criminal law means that an uncontroversial view of criminalisation is not possible. The interface with political tides means that convenience, just as much as principle, dictates the ambit of our criminal law. This does not mean, however, that we should shy away from trying to develop the scope of the criminal law in a principled way. Given that criminalisation is society's most extreme tool, we must strive with greater diligence to ensure that reason, not convenience, dictates the ambit of the criminal law.

\section{A The Desirability of Harm Minimisation as a Policy Strategy}

The criteria above are predicated on whether we can find harm, and if so, whether criminalisation is the best way to minimise that harm. It is important to analyse why harm is the

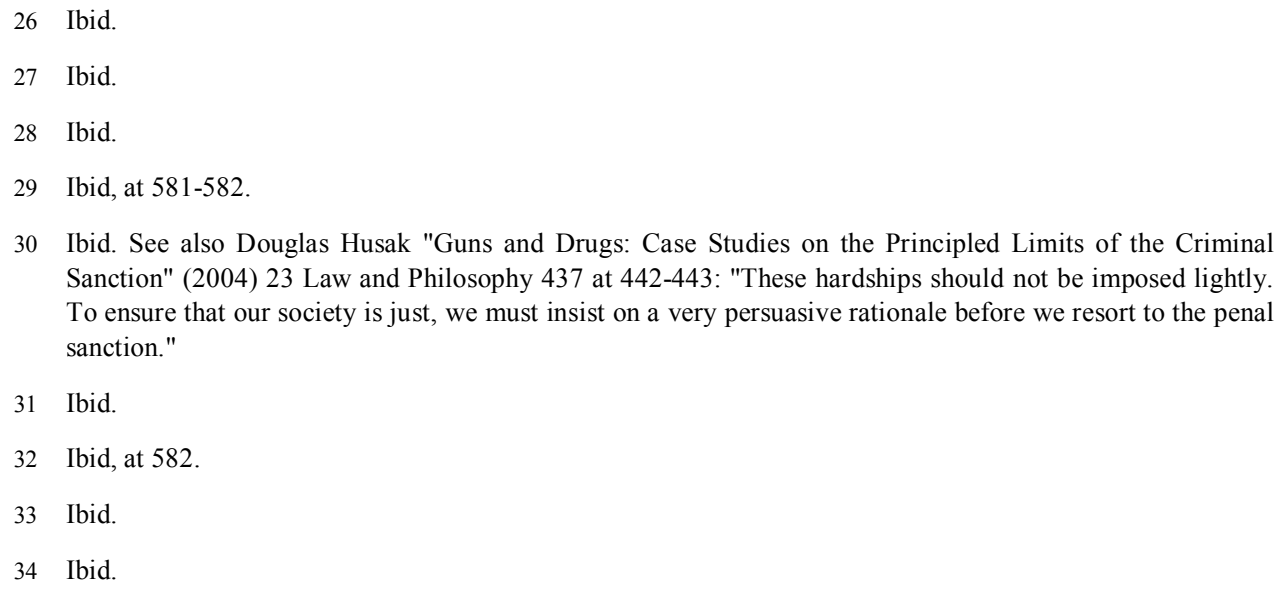
Sanction" (2004) 23 Law and Philosophy 437 at 442-443: "These hardships should not be imposed lightly. To ensure that our society is just, we must insist on a very persuasive rationale before we resort to the penal sanction."

31 Ibid.

32 Ibid, at 582.

33 Ibid. 
most important metric, and why we should seek to use harm minimisation as a policy basis. This will address the first of the Law Commission's terms of reference. ${ }^{35}$

At present there is a competing tension between the punitive legislative scheme and a policy of harm minimisation. This tension is highlighted by the National Drug Policy 2007-2012 report because it accepts a policy of harm minimisation. ${ }^{36}$ Harm minimisation accepts that the elimination of 'high-risk' behaviour is not feasible; therefore policies should focus on minimising the harm that comes from the activity rather than trying to eliminate the behaviour. ${ }^{37}$ We must review what the purpose of criminalisation is in this case to determine whether we should adopt a policy of harm minimisation.

\section{Moral or regulatory?}

Often the reasoning for criminalisation falls into two categories. Criminalisation can either be used as a moral and retributive system, or it can be used as "a regulatory, instrumental, or utilitarian" mechanism, which "prohibits certain things on grounds of public health or safety, or for economic and political reasons. [This approach] ... sees the purpose of punishment as deterring that behaviour". 38

The difficulty in sustaining an argument for a moral and retributive system in relation to drugs is fourfold. First, there is an arbitrary distinction between legal and illegal drugs. What is moral about caffeine, but immoral about benzylpiperazine (BZP)? The New Zealand Drug Foundation said that: ${ }^{39}$

... as a philosophical basis for drug policy, the justice perspective is very limited. Its underlying premise, that illegal drugs are 'bad' while legal drugs are generally 'good', is too black and white to be credible.

Second, many illegal substances occur naturally in the body such as dimethyltryptamine (DMT), making the imposition of morality difficult. ${ }^{40}$ Third, a view based on morality still incorporates

35 New Zealand Law Commission, above n 4, at [a], [b].

36 Ministerial Committee on Drug Policy National Drug Policy 2007-2012 (Ministry of Health, Wellington, 2007)

37 New Zealand Drug Foundation Through the Maze - Healthy Drug Law Reform (Wellington, 2009) at $7<$ www.nzdf.org.nz>.

38 Nicola Lacey, Celia Wells and Oliver Quick Reconstructing Criminal Law (3rd ed, LexisNexis UK, 2003) at 4 .

39 New Zealand Drug Foundation, above n 38, at 2.

40 S A Barker, J A Monti and ST Christian "N,N-Dimethyltryptamine: An Endogenous Hallucinogen" (1981) 22 International Review of Neurobiology 83. 
harm as its metric, the harm being an offence to morality. This view seeks only to broaden the definition of harm, not challenge the use of the metric.

Fourth, a retributive system is about 'just deserts', punishing an offender for the harm they have caused to another. ${ }^{41}$ This is best understood when a victim potentially gets retribution for the harm inflicted. ${ }^{42}$ However, drug taking often has no direct victim. It does not seem credible to suggest society, as an alleged victim, wants retribution upon an addict for their addiction. It is rather secondary actions, like violence, which society wants to punish.

These points suggest that criminalisation is regulatory, not moral, used to deter individuals from engaging in a specific activity. The reason drug use falls into this category is because there is a purported propensity for people to engage in secondary activities that society does deem to be morally reprehensible, such as violence. This means we want to minimise the number engaging in drug use in the first place. Criminalisation of drug use itself, however, does not seem to be justified on the grounds of moral retribution.

Given that the purpose of criminalisation in the context of drug use is regulation and deterrence, it is inherent that harm minimisation is a key tenet. The reason the activity is being regulated in the first place is to try and limit the associated harms that accrue from that activity, not because of its inherent immorality. It is asserted by many that fewer harms result when drug use is illegal because fewer people engage in it, minimising the amount of associated harm. Therefore, for the law to intervene it must demonstrate that it is effective at minimising harm.

The use of criminal law should be as a "last resort". ${ }^{43}$ Criminalisation therefore must only occur when it can be shown that it actually minimises harm, and that it is the most effective method of minimising harm.

\section{B Harm Principle}

It is important to define and clarify what is meant by 'harm' in the context of criminalisation. Often, criminalisation is supported when it intervenes to stop the infliction of unwanted externalities, or 'harm', on a non-consenting party. ${ }^{44}$ Viewed as a negative restraint, the absence of harm, dictates that there must also be an absence of State intervention. ${ }^{45}$ This does not posit that where harm exists so too should State intervention; that can only be decided when the negative case

41 Andrew Ashworth Sentencing \& Criminal Justice (3rd ed, Butterworths, London, 2000) at 72-74.

42 Ibid.

43 Andrew Simester, above n 26, at 581. See also Board of Health Committee, above n 8, at 48.

44 J S Mill On Liberty (Penguin, Harmondsworth, 1974) at Chapter 1, [9].

45 Andrew Simester, above n 26, at 583. 
for criminalisation has also been made out. ${ }^{46}$ The inability to define harm, however, has left this restraint imprecise. Subsequent scholars have widened the definition of harm. ${ }^{47}$

Feinberg's analysis posits that harm is the "thwarting, setting back, or defeating of interest[s]". 48 Interests are those things in which an individual has a stake in. ${ }^{49}$ These 'things' are distinguished from other interests by their link to the advancement or detriment of the individual themselves. ${ }^{50}$ Harm, therefore, consists of a setback to interests which prohibits or is detrimental to the advancement of an individual. If this happens, the State is justified in criminalising the activity of the offender because it conflicts with the interests of 'the other' - defining a positive case for state intervention. ${ }^{51}$

The idea of 'the other' having their interests set back is not confined to individual entities. It can be tied to an entity that aggregates collective interests, such as society or government. Actions such as tax avoidance, therefore, can be considered criminal. ${ }^{52}$ This is because the interests which the collective has in the revenue of tax are set back by the skulduggery of an individual. Hyman Gross encapsulates this broad definition in four categories of harm: ${ }^{53}$

(i) Violations of interest in retaining or maintaining what one is entitled to have;

(ii) Offences to sensibility;

(iii) Impairment of collective welfare;

(iv) Violations of governmental interests.

To justify the criminalisation of a certain act, one must identify to which of the above categories the harmful effect occurs. ${ }^{54}$ The idea that drug consumption should be illegal because it is immoral to harm oneself should not be accepted. One must tie it to a specific harm to 'the other', like the impairment of collective welfare due to the socialisation of healthcare costs.

46 Ibid.

47 Ibid.

48 Joel Feinberg The Moral Limits of the Criminal Law, Volume 1: Harm to Others (Oxford University Press, New York, 1984) at 33.

49 Ibid, at 34.

50 Ibid.

51 Andrew Simester, above n 26, at 583.

52 Ibid.

53 Hyman Gross A Theory of Criminal Justice (Oxford University Press, New York,1979) at 119-121

54 Herbert Packer The Limits of Criminal Sanction (Stanford University Press, California, 1968) at 262. See also Andrew Simester, above n 26, at 583. 
It is not the author's aim to question the validity of this definition here. If personal drug use and possession does fall within this wide definition of harm, there will be a positive case for criminalisation. However, it must be shown that there are no other appropriate alternatives before we should accept criminalisation. This is the requirement that the negative criterion imposes.

\section{A POSITIVE CASE FOR CRIMINALISATION}

We now analyse whether a positive case for criminalisation can be made out. Prima facie, drug consumption falls within Gross' third category. The collective welfare is set back by the consumption of drugs, predominately because healthcare costs are socialised. Young argues that the most "fundamental criterion of drug abuse is health risk". ${ }^{55}$ The greatest harm coming from drugs is the risk that it has to the health of an individual. This becomes prima facie worthy of criminalisation when it begins to impair the collective welfare. As more people rely on the healthcare system the ability to apply resources to other areas diminishes affecting the collective welfare.

There may be costs associated with drug use, such as a potential for violence. There are significant problems with this as a positive basis for criminalisation. First, it is unclear whether violence occurs because of some drugs, or because of the criminalisation of said drugs. It is likely that both cause violence, but even conceding this, the possession and consumption of drugs may only be likely to cause violence, they do not necessarily cause violence. This means that violence is a step removed from the actual possession or use. A positive case to criminalise violence is able to be made out, it is not so clear for drug consumption. In light of this, violence is not a principled reason for criminalisation. However, it may be a reason that we would want to control drug use in other ways.

The major claim for a positive case of criminalisation, therefore, rests on the grounds of direct healthcare costs. Individuals harm society's interests because they inflict a cost on the healthcare system. The author acknowledges that there may potentially be other externalities, but confines the analysis to dealing with this substantive claim.

What is unclear, however, is the threshold of harm needed to constitute a positive case for criminalisation. The inability to distinguish drug use from other inflicted externalities renders this claim problematic. It seems logical that the gravity of impact should be the primary test for criminalisation. In theory, once an activity goes over the threshold of harm that activity should be criminalised. Collective interests, however, are set back by the over-consumption of food, alcohol, and cigarettes. In fact, the harm from fatty foods and cigarettes is acknowledged to be one of the most expensive externalities. ${ }^{56}$ It is clear that not all externalities are criminalised. What is not clear is the threshold one has to meet in relation to the setback of the collective welfare to be criminalised.

55 Jock Young The Drugtakers: The Social Meaning of Drug Use (MacGibbon \& Kee, London, 1971) at 222.

National Drug Policy, above n 37, at 25. 
It seems that a threshold of harm is not the determining factor for criminalisation. This is evidenced by the United Kingdom Report which concluded: ${ }^{57}$

... on the evidence ... it would be reasonable to judge cannabis less of a threat than alcohol or tobacco ...

on the medical evidence available, moderate indulgence in cannabis has little ill-effect on health ...

The lack of correlation between legal status and the gravity of harm inflicted leaves the positive justification for criminalisation at issue. This is especially pertinent for most Class B and C drugs. ${ }^{58}$

To take the analysis one step further, one could contend that in principle fatty foods, alcohol and cigarettes should all be criminalised. Many describe the lack of criminalisation of cigarettes and alcohol as a historical anomaly. If cigarettes and alcohol were introduced today they would be criminalised. This would restore a principled threshold for criminalisation. ${ }^{59}$

If we are to accept the principle that there is a threshold of harm, we must reanalyse whether drug use actually reaches this threshold. If it does, then other things like extreme sports, fatty foods, and even potentially rugby would be prima facie criminal. These are all likely to have the same, if not worse, externalities on our healthcare system in the aggregate than drugs. This does not seem credible.

The author asserts that if we pursue certain policy objectives that socialise costs, we should not use them to justify criminalising certain behaviour that would otherwise not be. We must create these institutions with the knowledge that people, through pursuing their idea of the good life, will end up using them. It is not an issue that can be distinguished on relative utility, such to say, there is more utility gained from snowboarding than from cigarettes. Utility by it very nature is subjective and can only be understood and gained by those individuals. The focus on freedoms in our society, such as speech and movement, is a concession to this idea. ${ }^{60}$ Only by minimising intervention into the individual's life can they pursue what they believe to be the good life. This is why criminalisation is a last and not a first resort. ${ }^{61}$

57 Police Foundation Report of the Independent Inquiry into the Misuse of Drugs Act 1971 (United Kingdom, 1999) <www.druglibrary.org $>$.

58 Misuse of Drugs Act 1975, Schedule 1.

59 As an aside, there may be an additional argument that applies to cigarettes but not to alcohol or fatty foods. Second-hand smoke is a direct cost to others. However, it is unclear whether it would meet the criminalisation threshold. Moreover, it is hard to compare this with illicit drugs. Most illicit drugs do not have a direct impact on other people, either because the drugs are not smoked or because they do not have the same social acceptance to be smoked in public areas. This diminishes the direct externalities inflicted.

60 New Zealand Bill of Rights Act 1990, ss 14 and 18.

61 Andrew Simester, above $\mathrm{n} 26,581$. See also Board of Health Committee, above $\mathrm{n} 8$, at 48 . 
The author believes, therefore, that Feinberg's analysis must be further refined. Impairment to the collective welfare should only be a prima facie reason for criminalisation where society has inflicted upon them externalities that they do not intend to pay the cost for. Healthcare costs, therefore, should never be a reason to criminalise an activity. This is because there would be a positive justification to criminalise almost all activities, which would be contrary to the principle of the criminal law as a last resort.

In the author's view a positive case has not been made out because there has not been a principled case for criminalising the use of drugs. Associated behaviour that goes with drug use, such as violence, may lead us to posit that we would like some control over drug use and possession, but it does not justify criminalisation. It has failed to meet the third category of harm as posited by Gross. ${ }^{62}$

\section{A NEGATIVE CASE FOR CRIMINALISATION}

Regardless, however, of whether a positive case for criminalisation exists, the author contends that a negative case would not be made out.

The burden of a negative case limits the use of the criminal law even when a positive case is made out by making those that advocate the use of criminalisation prove that it is the best regulatory tool available. ${ }^{63}$

The negative justification for intervention is based on the assumption that an alleged setback to the collective interests will be mitigated because drug consumption is less when drugs are criminalised. New Zealand follows this punitive approach where users are dealt with under the criminal system. The author would like to analyse an alternative approach currently adopted by Portugal. It will then be possible to compare the models to see which one best reduces harm.

\section{A Portugal's Model}

In the 1990s Portugal experienced a rapid increase in non-medical drug use. This centred principally, but not exclusively, on heroin. ${ }^{64}$ In the wake of this the Commission for a National Drug Strategy (CNDS) was initiated. In 1998, the CNDS released a report - Comissão para a Estratégia Nacional de Combate à Droga 1998 - which suggests a major shift towards harm

62 Hyman Gross, above n 54, at 119-121.

63 Andrew Simester, above n 26, at 582.

64 Mirjam van het Loo, Ineke van Beusekom and James Kahan, above n 6, at 50-62. 
minimisation in Portuguese drug policy. ${ }^{65}$ The "flagship of these laws [was] the decriminalisation of the use and possession of drugs". ${ }^{66}$

In July 2001 the report was approved, almost in its entirety, by the Assembleia da Republica (Parliament). ${ }^{67}$ The effect of subsequent legislation was to decriminalise all drugs, placing administrative rather than criminal sanctions on the use and possession of drugs. ${ }^{68}$ Whilst other countries across the world have developed de facto decriminalisation policies, Portugal is the only country that has adopted an explicit decriminalisation policy enshrined in law. ${ }^{69}$ After eight years of decriminalisation we can now start to assess the impact of such a shift.

\section{How does Portugal's System Work?}

In Portugal what the CNDS recognised, and the government conceded, was that the criminal system's attempt to contain drug use was shown to be neither appropriate nor effective. ${ }^{70} \mathrm{By}$ decriminalising drug use, Portugal separated out the user from the supplier and accepted that different measures were appropriate. Due to international obligations legalisation that decriminalised manufacture and supply was rejected. ${ }^{71}$ There was a strong desire to make sure that Portugal's legislative change was not "outside of the mainstream of international drug policy". ${ }^{72}$ However, "Portugal [was] determined to implement a coherent and comprehensive strategy based on the philosophy of harm reduction". ${ }^{73}$ Portugal relied on humanistic and pragmatic principles to support decriminalisation. ${ }^{74}$ These principles sought to recognise drug users as "full members of society" who did not deserve to be criminalised. ${ }^{75}$ Portugal has done this by going much further than its contemporaries like Spain and the United States, who rely on conviction or criminal procedure

65 Ibid, at 50.

66 Glenn Greenwald Drug Decriminalization in Portugal, Lessons for Creating Fair and Successful Drug Policies (CATO Institute, 2009) at $6<$ www.cato.org $>$.

67 Mirjam van het Loo and others, above n 65, at 50.

68 Glenn Greenwald, above n 67, at 3.

69 Ibid, at 1.

70 Mirjam van het Loo and others, above n 65, at 57.

71 Glenn Greenwald, above n 67, at 6.

72 Mirjam van het Loo and others, above n 65, at 55.

73 Ibid

74 Ibid.

75 Ibid. 
before treatment is offered. ${ }^{76}$ Portugal, on the other hand, has completely removed drug use from the criminal realm.

Decriminalisation, however, was seen only as a first step. Portugal wanted to extend preventative measures to: ${ }^{77}$

... primary prevention, in schools, families, and the community in general. Harm reduction measures (in the narrow sense of the term) include needle and syringe exchange, shooting rooms, information and motivation centers, [sic] and substitution programs [sic].

\section{Procedure}

The process for those found with illicit drugs is as follows. If one is caught by a police officer, that officer is required to issue a citation. They are not, however, permitted to arrest the individual. ${ }^{78}$ It does not matter whether the drug is "hard or soft". ${ }^{79}$ The citation is passed on to the "Commission for Dissuasion of Drug Addicts", the administrative body that oversees the response. ${ }^{80}$ Across the country specialist "Dissuasion Commissions" have been set up. These Commissions consist of three people: two come from the medical sector - physicians, psychologists, or social workers; and the other has a legal background. ${ }^{81}$ The offender appears in front of the Commission within seventy-two hours of the incident. ${ }^{82}$ If the evidence shows that the individual had more than the average dose for ten days, the Commission will refer that individual to the criminal system for presumed trafficking and supply. ${ }^{83}$ Otherwise, the Commission has the ability to inquire and gain evidence as to the nature, context and circumstances of the individual's drug use. ${ }^{84}$ The Commission makes a determination as to whether the individual is a non-addicted user or an addicted user.

For non-addicted users the Commission may impose a fine or an oral warning. Fines are expressly only to be used as a last resort. ${ }^{85}$ If, however, the non-addicted offender has no prior offences the Commission is required to suspend proceedings and impose no sanction. ${ }^{86}$

76 Ibid, at 58 .

77 Ibid, at 57.

78 Glenn Greenwald, above n 67, at 4.

79 Ibid, at 3.

80 Ibid, at 4.

81 Mirjam van het Loo and others, above n 65, at 58. These positions are appointed by the Minister of Health and the Minister of Justice respectively.

82 Ibid.

83 Glenn Greenwald, above n 67, at 4.

84 Ibid, at 3.

85 Ibid. 
Where the offender is found to be an addicted user, the Commission has a range of administrative 'penalties' available to it. Article 17 outlines these penalties. They include: the removal of a licence to practice of professionals; fines; ban on associating with specific people or places; periodic reports to the Commission; termination of allowances/benefits; or, oral warnings. ${ }^{87}$ The Commission has the sole discretion as to what penalty, if any, to impose. They have a series of factors to consider, which includes: seriousness of the act; type(s) of drugs consumed; and, public or private use. ${ }^{88}$ The Commission, however, must suspend proceedings if the offender agrees to undergo treatment. ${ }^{89}$ The individual offender is allowed to request a therapist to aid him or her through the proceedings and can opt for a medical examination to assist the Commission's decision. ${ }^{90}$ Minors go through the same administrative process. They are aided by legal representation who are able to make decisions on their behalf. ${ }^{91}$

As a result, in 2005:

... there were 3,192 commission rulings. Of those, 83 percent suspended the proceedings; 15 percent imposed actual sanctions; and 2.5 percent resulted in absolution. ... Of the cases where sanctions were imposed, the overwhelming majority merely required the offenders to report periodically to designated locales.

\section{B Comparing New Zealand and Portugal}

Like alcohol, illegal drugs cause considerable harm. The key question is what approach will most effectively mitigate that harm? ${ }^{92}$

We can now compare New Zealand's and Portugal's models to see which minimises associated harms better. This will address the Law Commission's second term of reference. ${ }^{93}$ If Portugal better minimises harm this will mean that a negative case for criminalisation fails. The author has identified three areas of comparison. The first and most significant is the idea of deterrence. Which system has been best able to contain drug use? Second, which system offers the best treatment to users? Third, which model has greater secondary flaws?

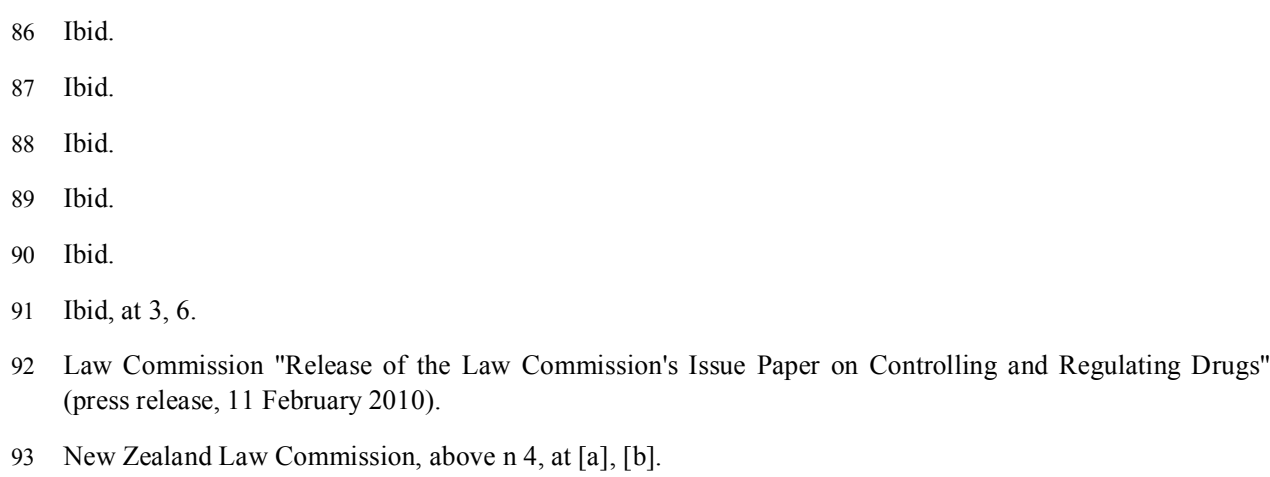




\section{Deterrence}

(a) New Zealand - A punitive approach

At the heart of criminalisation of possession and consumption of drugs is the belief that individuals will be deterred from those activities. By criminalising an activity the State increases the cost of that activity by the imposition of a sanction. Deterrence is purported to be effective because individuals believe the cost to be greater then the benefit from engaging in that act. ${ }^{94}$ The extent of the deterrence will be determined when the cost of engaging in an activity is balanced against the perceived likelihood of being caught and the likely cost of sanctions that will occur from being convicted in the justice system. ${ }^{95}$ This works on both a "general" and "specific" level. ${ }^{96}$ It works generally in the sense of deterring the public from engaging in the activity and specifically in the sense of discouraging already identified offenders from re-offending. ${ }^{97}$

The single greatest indictment on the efficacy of deterrence in the realm of drug possession and consumption is the failure to halt the growth in drug use. ${ }^{98}$ Statistics suggest more people had tried illegal drugs in 1998 than in $1990 .{ }^{99}$ Once again, between the period of 1998 and 2001 more people had tried drugs in 2001 than in $1998 .{ }^{100}$ The number of individuals currently using 'any stimulant' was at 1.1 per cent in 1990; 2.3 per cent in 1998; and, 3.7 per cent in 2001. ${ }^{101}$ This trend is witnessed internationally. ${ }^{102}$

A further indictment of the status quo is that the Police have de-emphasised their punitive approach as illustrated by the report Illicit Drug Strategy to $2010 .{ }^{103}$ This report focuses on alternative tactics such as educational programmes and makes no mention of the efficacy of a

94 Andrew Von Hirsch and others Criminal Deterrence and Sentence Severity An Analysis of Recent Research (Hart, Oxford, 1999) at 4.

95 Andrew Ashworth, above n 42, at 64.

96 Andrew Von Hirsch and others, above $\mathrm{n} 95$, at 5.

97 Ibid.

98 Adrian Field, Sally Casswell, above n 2, at 39-45. See also, Alcohol and Public Health Research Unit, above n 2, at 42. See Appendix 1.

99 Adrian Field, Sally Casswell, above n 2, at 39.

100 Alcohol and Public Health Research Unit, above n 2, at 42.

101 Adrian Field, Sally Casswell, above n 2, at 44. See also Alcohol and Public Health Research Unit, above n 2, at 42. See Appendix 1.

102 Michael Shiner "Drugs, Law and the Regulation of Harm" in Rhidian Hughes, Rachel Lart, Paul Higate (eds) Drugs: Policy and Politics (Open University Press, Berkshire, 2006) at 68.

103 New Zealand Police Illicit Drug Strategy to 2010 (Wellington, 2009) <www.police.govt.nz>. 
punitive approach. ${ }^{104}$ Moreover, when individuals do come into the criminal system the growing response has been to remove them from the system. The adult diversion scheme, although limited in scope, has brought an important element of restorative justice to the catalogue of responses. ${ }^{105}$ The need for restorative justice processes is increasingly being recognised. ${ }^{106}$

A report released by the Police Foundation in the United Kingdom, accepts that: ${ }^{107}$

... such evidence ... about the current situation and the changes that have taken place in the last 30 years

all point $[\mathrm{s}]$ to the conclusion that the deterrent effect has been very limited.

Whilst there are a myriad of explanations that could provide reasons for this failure, the author will focus on the most prominent.

The use of drugs is a victimless crime in the sense that there is no party interested in being the plaintiff. ${ }^{108}$ This has two implications. First, the ability to catch people using drugs is greatly diminished; the risk of being caught is small. The large amount of resources and large abrogation of offenders' rights that the Police would need to be able to catch these people is neither viable nor desirable.

Second, given the threat of punishment cannot be relied upon to deter individuals, the deterrent needs to rely on the target audience internalising the standard or norms "to help bring about compliance". ${ }^{109}$ This involves a "normative commitment" where those people and society are "convinced, or become convinced, of the wrongfulness of the conduct". ${ }^{110}$ This is intimately wrapped up in legitimacy of government intervention. Society needs to believe that the criminalisation of the conduct is a proper exercise of the State's authority. ${ }^{111}$ In relation to drug possession and consumption, it is not clear that the target audience has internalised these norms.

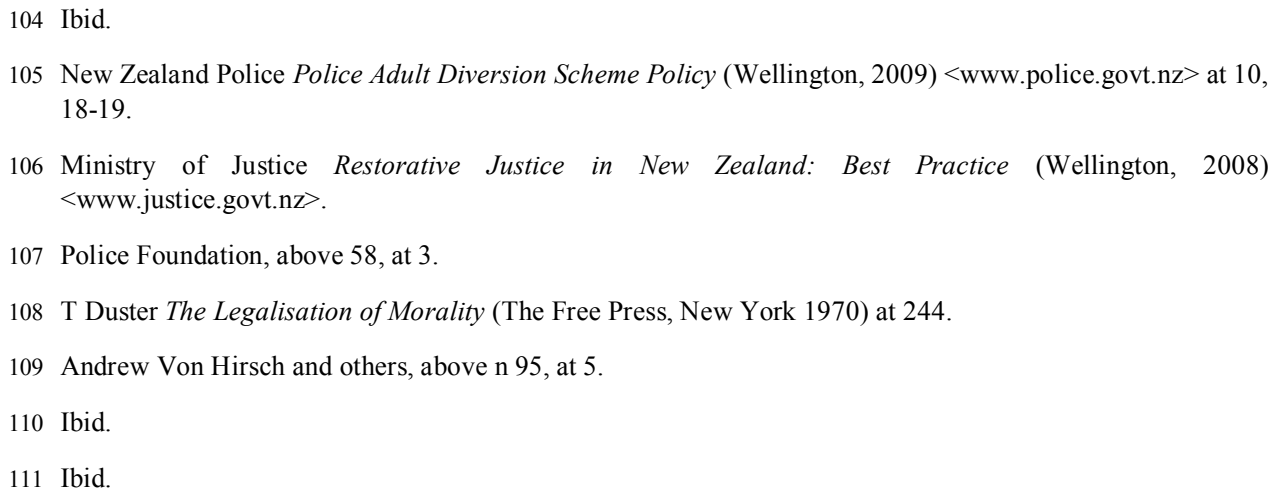


More importantly, many people are changing their views with regard to these norms. Both are evidenced by increased drug use. ${ }^{112}$

This increase may be due to the arbitrary nature of the law in relation to legal and illegal drugs. ${ }^{113}$ As people experience illegal drugs within their peer groups - especially drugs like ecstasy, LSD, and cannabis - they come to realise that the treatment of those illicit drugs has been greatly exaggerated. ${ }^{114}$ This is amplified when substances such as BZP are made illegal. Individuals who had no adverse experience with BZP when it was legal become cynical towards the information provided in relation to harm. ${ }^{115}$ The credibility of a punitive system is called into disrepute with the continued assertion that these drugs are more harmful than legal drugs.

(b) Portugal - the alternative

Opponents of decriminalisation in Portugal said that if criminal sanctions were removed, drug consumption would sky-rocket. ${ }^{116}$ This is based on an intuitive argument if drugs are no longer subjected to criminal sanction, consumption will increase. None of the fears that dominated the predecriminalisation debate have been realised - neither a rapid increase in drug use, nor an increase in drug tourism. ${ }^{117}$ The Portuguese experience has been different since decriminalisation. In absolute terms: ${ }^{118}$

$\ldots$ drug usage in many categories has actually decreased ... whereas usage in other categories has increased only slightly or mildly. ... In almost every category of drug, and for drug usage overall, the lifetime prevalence rates [which measure how many people have consumed a particular drug or drugs over their lifetime] in the pre-decriminalization era of the 1990s were higher than the post decriminalisation [era].

$\cdots$

Life time prevalence rates in Portugal have decreased for various age groups ... in fact, for ... two critical groups of youth (13-15 years and 16-18), prevalence rates have declined for virtually every substance since decriminalisation ...

112 Adrian Field, Sally Casswell, above n 2, at 39-45. See also, Alcohol and Public Health Research Unit, above $\mathrm{n} 2$, at 42. See Appendix 1.

113 New Zealand Drug Foundation, above n 38, at 2. See also Police Foundation, above n 58.

114 Michael Shiner, above n 103, at 67. See also Jock Young, above n 59, at 222. Police Foundation, above n 58 .

115 Michael Shiner, above n 103, at 67. See also Jock Young, above n 59, at 222.

116 Glenn Greenwald, above n 67, at 1. See appendix 2.

117 Ibid.

118 Ibid, at 11-15. 
Similar reductions have occurred in countries with implicit policies of decriminalisation. The Netherlands saw a fall in the use of cannabis rates after de facto decriminalisation in $1976 .{ }^{119}$ This lead many to the conclusion that: ${ }^{120}$

There is no correlation between the harshness of drug laws and the incidence of drug-taking: citizens living under tough regimes (notably America but also Britain) take more drugs, not fewer. Embarrassed drug warriors blame this on alleged cultural differences, but even in fairly similar countries tough rules make little difference to the number of addicts: harsh Sweden and more liberal Norway have precisely the same addiction rates.

By moving drug use into the administrative realm Portugal has been able to largely mitigate the problems presented under a punitive system. First, this change continues to restore legitimacy in the Government's approach to drug users. This is witnessed by the continued growth in popularity of the change amongst the public. ${ }^{121}$ There is little debate surrounding whether re-criminalisation is warranted or desirable. ${ }^{122}$ Second, although the approach has not completely eliminated the divide between legal and illegal drugs, it has largely mitigated the difference, meaning that people do not feel the law is as illogical as before.

It is clear that on the first comparison the Portuguese model has offered a better approach than the status quo in New Zealand.

\section{Treatment}

\section{(a) New Zealand}

As aforementioned, one of the rationales behind the MODA was to introduce a dual system, where criminalisation was used as a "last resort", and treatment as the first. ${ }^{123}$

... the committee is firmly committed to the view that the law should be regarded not as the first line of defence against harm but rather as the last resort, setting the limits within which other and preferably positive sanctions should be brought into play.

The inability of the punitive system to stem drug consumption is largely due to the inability to implement a dual system in New Zealand. There has been a great divide between what was intended

119 J P Morgan, D Riley, G B Chesher "Cannabis: Legal Reform, Medicinal Use and Harm Reduction" in Nick Heather, Alex Wodak, Pat O'Hare (eds) Psychoactive Drugs and Harm Reduction: From Faith to Science (Whurr, London, 1993).

120 Editorial "Failed States and Failed Policies: How to Stop the Drug Wars" The Economist (London, 5 March 2009) <www.economist.com>.

121 Even though there is widespread perception that bureaucratic changes need to be made.

122 Glenn Greenwald, above n 67, at 1.

123 Board of Health Committee, above n 8, at 24. 
and what has actually occurred. This point has been conceded with the release of the two National Drug Policy reports by the Ministerial Committee in 1998 and 2007. ${ }^{124}$ These reports highlighted the need to expand non-punitive policy responses in the face of increased drug use. ${ }^{125}$ This view has been confirmed by the Ministry of Health's report in 2005, which called for an improvement in the availability and access to quality addiction services. ${ }^{126}$

The implementation of a dual model has been hampered by the narrow and punitive focus of the MODA. Alternative policies have not been implemented to any great extent despite the intention by legislatures for the past 34 years. ${ }^{127}$ The reason for this is that a dual system, with a large focus on rehabilitation and less on punishment, is not possible. They are mutually exclusive approaches. When the approach to drug consumption is punitive, the illegal status of those drugs means that a punitive system has to be the dominant mechanism used to reduce the harms from those drugs. For most of the harm minimisation policies to come into effect for the user they must identify themselves as a user. There are only two ways to do this: volunteer or be arrested. Voluntary application to programmes is unlikely to occur when the state both prosecutes and provides help to the same offenders. The perceived risk of imprisonment is a risk offenders are unlikely to take. This is because criminal sanctions use "threats and fear" to deter individuals. ${ }^{128}$ It is no surprise that those users do not want to take the risk of being subjected to punishment. There is a signalling problem here; the law is putting out contradictory messages. If deterrence is going to work, it needs to signal that any threats are going to be carried through and will be serious. If the State wants to medically treat people it needs to show the opposite, a willingness to help and not punish. One must give way to the other. At the moment we continue to emphasise the former rather than the latter.

The same problem faces private groups who seek to help offenders. They suffer the same participation issues due to a perceived risk of being moved into the criminal justice system. Further, private groups face an even more stark contradiction because they are providing a service that may help offenders in the commission of an illegal offence.

It might be conceded, however, that often the legal sanctions precipitate treatment as it helps offenders realise the problems that the may have. This point is only effective if it can prove that it is the best way to show people that they have a problem, a point that will be closely analysed below.

124 Ministry of Health National Drug Policy 1998-2003 (Wellington, 1997). See also, National Drug Policy, above $\mathrm{n} 37$.

125 National Drug Policy, above n 37, at 3.

126 Ministry of Health "Te Tahuhu - Improving Mental Health 2005-2015: The Second New Zealand Mental Health and Addiction Plan" (Wellington, 2005) <www.moh.govt.nz>.

127 National Drug Policy, above n 37, at 17. See also Ministry of Health, above n 128.

128 Andrew Ashworth, above n 42, at 64. 
The author contends that to increase numbers entering into alternative policies the State will have to continue to put resources heavily into a punitive approach to get offenders involved. This contravenes a primary objective of restorative and therapeutic justice: the importance of voluntary subscription. ${ }^{129}$ Accepting this proposition means that a binary choice is created. One must either accept a system that has a primary focus on punitive measures, or one has to accept a system that moves away from the illegal status of drugs so that resources can focus upon treatment as an alternative.

(b) Portugal

Portugal pre-2001 had the same problem as New Zealand does now. Drug use was increasing and rehabilitation rates were low due to participation issues and lack of resources. ${ }^{130}$

... Portuguese drug officials confirmed that before decriminalisation, the most substantial barrier to offering treatment to the addict population was the addicts' fear ... particularly from the state agencies ...

of being arrested.

However, those seeking treatment for addiction in the post-decriminalisation period has increased by 147 percent, from 6,040 in 1999 to 14,877 in $2003 .{ }^{131}$ There has also been a rise in the number of individuals seeking detoxification, therapeutic communities and half-way houses. ${ }^{132}$ This vast rise has been linked to the removal of criminal sanctions from using drugs. ${ }^{133}$ The Portuguese have been able to reallocate resources away from punitive measure and into treatment facilities. ${ }^{134}$

Further, it must be noted that there have been significant health benefits achieved. The percentage of drug users who are newly-infected with HIV has been in substantial decline. ${ }^{135}$ "Between 1999 and 2003 there was a 17 per cent reduction in the notifications of new [HIV]

129 Ministry of Justice Restorative Justice in New Zealand: Best Practice (Wellington, 2004) at 11 $<$ www.justice.govt.nz>.

130 Glenn Greenwald, above n 67, at 8-9.

131 Caitlin Hughes, Alex Stevens The Effects of Decriminalization of Drug Use in Portugal (Beckley Foundation Drug Policy Programme, Oxford, 2007) at 2, 5.

132 Ibid.

133 Glenn Greenwald, above n 67, at 16.

134 Ibid.

135 Ibid. 
cases". ${ }^{136}$ In fact, across nearly every health indicator of harm, they have had positive results. ${ }^{137}$ Infections of hepatitis $\mathrm{B}$ and $\mathrm{C}$ are down, so too are mortality rates associated with drug use. ${ }^{138}$

If we compare to similar countries in the European Union: ${ }^{139}$

In the context of these EU-wide trends, usage rates in postdecriminalized Portugal are notably low.

Indeed, as a 2006 report on Portuguese drug policy concluded, five years after decriminalization, "The

prevalence of drugs in Portugal, both in general and the school population, is below the EU average.

The last point of contention: it might be conceded that legal sanctions often precipitate treatment. However, the rate of uptake of treatment in Portugal after decriminalisation seems to suggest that the greatest barrier to seeking treatment comes from people worried about criminal sanction rather than them not knowing they have a problem.

It is clear that on the second comparison, the Portuguese model has offered a better approach than the present status quo in New Zealand. They have the ability to offer more treatment to users and have been able to attract users into accepting treatment.

\section{Critique}

(a) New Zealand - Labelling Theory

Labelling a user as criminal purportedly has the positive benefit of deterrence. Having dispelled deterrence in the realm of drug use above, it is important to analyse the costs involved with labelling users. Many scholars contend that the justice system, through the use of labels, anchors people into a criminal career. ${ }^{140}$ This is because the use of labelling individuals as 'deviant' or 'criminal' can have a negative impact on the ability for the individual to re-engage with society once labelled. It is the author's contention that this is acutely felt with the realm of drug consumption. ${ }^{141}$

State intervention is criminogenic because it "dramatises evil". ${ }^{142}$ Only some individuals who engage in an illegal activity are caught, those individuals are then separated from their peer group and are given "special treatment". ${ }^{143}$ They are put through a series of institutions which label that

136 Ibid.

137 Ibid, at 16-19. See appendix 2.

138 Ibid.

139 Ibid, at 22.

140 J Robert Lilly, Francis T Cullen, Richard A Ball Criminological Theory: Context and Consequences (2nd ed, Sage, Thousand Oaks (CA), 1995) at 110.

141 Ibid.

142 Ibid, at 116.

143 Ibid. 
individual and make them self-conscious of their wrong. "Now the [defendant's] world is changed fundamentally ... made conscious of [themselves] as a different human being than he was before his arrest."144

The process ensures that there is a "self-fulfilling prophecy". ${ }^{145}$ People do not just condemn the conduct that the person has done, but often come to believe the person is worthy of condemnation. ${ }^{146}$ Once a criminal label is put in place the moral character of the individual is degraded by society. This is despite the fact that such "predictions about personal character and future behaviour are likely to be incorrect". ${ }^{147}$

This label, however, becomes the primary mechanism by which that individual is identified by the rest of society. ${ }^{148}$

$\ldots$ in the face of repeated designation as criminals, offenders are likely to forfeit their self-concept as conformists or "normal" ... [they increasingly] internalize their public definition as deviants.

Given the inability to prove the benefit of deterrence by the imposition of a label and the alleged propensity for young people to use drugs, it is important to make sure that we do not set them up to follow this self-fulfilling prophesy.

In 2006, 4,121 individuals were convicted on charges of cannabis use in New Zealand, 1,030 individuals in the same year were convicted for all the other drugs listed in the schedule of the MODA. ${ }^{149}$ The use of criminal sanctions has stigmatised those individuals as criminals. Due to this large number there have been two key concessions made to labelling theorists in New Zealand:

First, a pilot drug court for youth has just been initiated in Christchurch. ${ }^{150}$ This scheme follows in the footsteps of a global movement that has tried to adopt greater therapeutic justice policies into drug offences. ${ }^{151}$ In the United States since 1989, the number of drug courts has exponentially grown, there are now over a thousand drug courts which focus on adult offending. ${ }^{152}$ The issue with

144 Ibid.

145 Ibid, at 117.

146 Ibid, at 118 .

147 Ibid.

148 Ibid, at 119.

149 Bronwyn Morrison, Nataliya Soboleva, Jin Chong Conviction and Sentencing of Offenders in New Zealand: 1997 to 2006 (Ministry of Justice, Wellington, 2008) at 42.

150 Sue Carswell, Ministry of Justice Process Evaluation of the Christchurch Youth Drug Court Pilot (Wellington, Ministry of Justice, 2004) at 24.

151 Ibid.

152 Ibid. 
these courts, however, is that they maintain the involvement of the justice system, a point of contention that will be closely analysed below.

Second, diversion is another important concession. ${ }^{153}$ The original conception of diversion was to divert those who would normally come under the justice system and face labelling as an outcome. ${ }^{154}$ In theory this seems to have been a good step forward. In practice it has been a disappointment. ${ }^{155}$ This is because the system often does not divert those who may need diversion the most. The hard or habitual user is often thought of as the most worthy of sanction. ${ }^{156}$ The casual Class $\mathrm{C}$ user, however, who would likely be released in lieu of diversion, is the individual that benefits from the system. The use of diversion under the status quo has a rather negligible effect for those that it could be most effective for - the habitual user.

Labelling theory is not without its critics. It is often argued that many offenders are involved in crime before coming to the attention of the justice system. ${ }^{157}$ However, for the 4,121 individuals who are labelled as criminal for possessing marijuana, the likelihood that those individuals will come into contact with the justice system again increases fourfold. ${ }^{158}$ Given the inability to prove the benefit of deterrence, this harm is a significant indictment of the imposition of a label.

(b) Portugal's response to labelling theory

Portugal's move to decriminalise drugs explicitly removed stigmatisation from the process. ${ }^{159}$ By moving the sanctions into an administrative realm they have managed to abolish the State imposed stigma meaning those individuals can seek treatment without fear of labelling.

[The] removal of the stigma attached to criminal prosecution for drug usage would eliminate a key barrier for those wishing to seek treatment. Even those nations where drug users are not typically punished with prison - like Spain - the stigma and burden of being convicted of a criminal offense remain[s].

The Portuguese have gone further than just the removal of stigma. At every step in the process their approach is to de-emphasise and eliminate any notions of guilt from drug use. Instead they

153 Police Adult Diversion Scheme Policy, above n 106, at 18-19

$154 \mathrm{~J}$ Robert Lilly and others, above n 142, at 128.

155 Ibid.

156 Ibid.

157 Ibid, at 121.

158 Conviction and Sentencing of Offenders in New Zealand: 1997 to 2006, above n 151, at 42. Lesley Mcara and Susan Mcvie "The Usual Suspects? Street-life, Young People and the Police" (2005) 5 Criminal Justice 5 at $13-18$.

159 Glenn Greenwald, above n 67, at 9. 
emphasise treatment and other health related aspects. ${ }^{160}$ For example, the hearing is not set up like a court and the Commission members dress informally. ${ }^{161}$

It maybe that society continues to stigmatise those that use. However, Commission members are bound to maintain complete confidentiality of all proceedings. ${ }^{162}$

(c) Portugal - a critique

The first potential issue with Portugal's approach is with the administrative sanctions that a Commission can impose. This is because they are, in a practical sense, punitive. Although they come under the rubric of an administrative offence, they still have a punitive element. This continues to contravene the voluntary principle of restorative and therapeutic justice. ${ }^{163}$ It might be argued that Portugal has not gone far enough. However, Portugal kept this small use of sanctions to accord with international obligations. ${ }^{164}$ It is vital to note that in Portugal the use of sanctions has not been extensive. ${ }^{165}$ Even if it were, the removal of a criminal label and the increased treatment are a step in the right direction.

To take this analysis a step further, although there are still sanctions, these sanctions may allow the model to be more readily accepted in New Zealand. As aforementioned, a relinquishment in New Zealand of State control over drugs is not viable because of domestic and international pressure upon the State to control drugs. This model walks the line between addicts' rights and society's concerns. The author believes that under the status quo in New Zealand there has been a large abrogation of addicts' rights. A move to Portugal's model would be a step in the right direction.

The second potential issue is that rehabilitation may become an indeterminate sentence for addicts. Portugal, however, has allayed these concerns. The commission cannot authorise mandatory treatment, they can only suspend sanctions pending the completion of treatment voluntarily. ${ }^{166}$ This limits the ability for treatment to be indeterminate. Moreover, this is a greater problem within the criminal context where the Court can impose mandatory treatment.

The third issue is to do with whether the political climate in New Zealand is ready to accept such a model. Portugal retains a highly homogenous: culture, language, religion and ethnicity. ${ }^{167}$ This

\author{
160 Glenn Greenwald, above n 67, at 6. \\ 161 Ibid. \\ 162 Ibid. \\ 163 Principles of Best Practice for Restorative Justice Processes, above 107. \\ 164 Mirjam van het Loo and others, above n 65, at 55. \\ 165 Glenn Greenwald, above n 67, at 6. \\ 166 Glenn Greenwald, above n 67, at 3. \\ 167 Mirjam van het Loo and others, above n 65, at 51 .
}


may mean that the ability to implement social change is easier and more accepted given the shared tradition. Importantly, Portuguese have a strong political climate of individual autonomy and liberty, probably in response to the years of dictatorial leadership. ${ }^{168}$

New Zealand does not have the same kind of history making it potentially hard to implement such a policy. It seems, however, that the policy shift in Portugal had less to do with its homogenous culture and more to do with the epidemic problem of drug use. ${ }^{169}$ Drugs inflicted a vast amount of harm on Portugal's society. ${ }^{170}$ Again, New Zealand has not experienced the same level, thus the impetus to change may be less strong. However, as drug use increases in New Zealand, society will start to look for alternative ways to deal with this problem. Even if this were not true, it is important to again note that after decriminalisation in Portugal, the policy became even more popular as people saw the beneficial effects. ${ }^{171}$ There is always likely to be initial concern but the author believes that such a move in New Zealand would witness increasing support.

It is clear that on the third comparison, the Portuguese model has offered a better alternative than the present status quo in New Zealand, because it has removed one of the most significant barriers to entry into treatment.

The New Zealand approach, therefore, has failed to meet the negative requirements for criminalisation. Portugal has managed to provide an alternative that better meets the aims of harm minimisation than that of the New Zealand model.

Having established two criteria upon which we could analyse whether drug use and possession should be criminalised, it is the author's view that neither criterion has been met. Therefore, an approach that deals with possession and use outside of the criminal process like Portugal may be warranted.

\title{
VI CONCLUSION
}

Since the research for this paper was undertaken, the Law Commission has released its Issues Paper. ${ }^{172}$ In the Issues Paper the Commission has canvassed a wide range of options for reforming the MODA and related legislation. ${ }^{173}$ Although its final report will be shaped by the submissions it receives, it is possible to deduce the type of reform the Commission thinks is needed.

\author{
168 Ibid. \\ 169 Ibid. \\ 170 Glenn Greenwald, above n 67, at 1-3. \\ 171 Glenn Greenwald, above n 67, at 1 . \\ 172 Law Commission Controlling and Regulating Drugs (NZLC IP16, 2010). \\ 173 Ibid, at 8 .
}


It is clear that the Commission is broadly in favour of the conclusions reached in the first half of this paper. It agrees that harm minimisation is a desirable policy platform, and that the MODA is "poorly aligned" with the policy objectives that underlie harm minimisation. ${ }^{174}$

However, the Commission dismisses an approach based on the Portuguese experiment. ${ }^{175}$

We have also considered but discarded an option based on the Portuguese approach. Although this approach appears to have been effective in Portugal, we believe its infrastructure of Commissions of Dissuasion is too resource-intensive for New Zealand. In addition, we have concerns about some aspects of the approach including the level of coercion that is potentially applied through what is essentially a civil process.

The author does not believe that these criticisms are well founded. The claim of resourceintensity is not clearly justified in the Issues Paper. One of the benefits put forward by the Portuguese model was the redirection of current resources to treatment. "... [D]ecriminalization freed up resources that could be channelled into treatment and other harm reduction programs". ${ }^{176}$ The author concedes that this is an empirical question. However, the Commission should be open to a more thorough investigation, given the acknowledged benefits. The issue with potential coercion in the civil realm is also not well founded. In Portugal the Commissions of Dissuasion cannot authorise mandatory treatment, they can only suspend sanctions pending the completion of treatment voluntarily. ${ }^{177}$ The implementation of sanctions is also tightly controlled. ${ }^{178}$ The coercive power that criminal sanctions impose and the harmful effects of criminal labels are far more worrying than the potential for coercion that civil sanctions provide.

The emphasis of the Commission is on reforming the law within the context of criminal sanction: "formal cautioning scheme, an infringement notice regime, and greater use of diversion into education and treatment". ${ }^{179}$ This is likely to be, in part, a result of what the Commission believes is politically palatable. Although they reject a model like Portugal's it is heartening that the Commission is focused on providing treatment. The Commission accepts that "[s]imply punishing a drug user, without taking steps to address their drug use, is a wasted opportunity". ${ }^{180}$

174 Controlling and Regulating Drugs, above n 175, at [3.10].

175 Ibid, at [11.39].

176 Glenn Greenwald, above n 67, at 9.

177 Ibid, at 3.

178 Ibid

179 Law Commission "Release of the Law Commission's Issues Paper on Controlling and Regulating Drugs" (press release, 11 February 2010).

180 New Zealand Press Association "Drug law proposals set to be rejected" The National Business Review (New Zealand, 11 February 2010) <www.nbr.co.nz $>$. 
It must be noted that the Commission's call for greater treatment is not new. The idea of focusing on treatment but having criminalisation as a last resort has been talked about since the Board of Health released their second report in 1973. ${ }^{181}$ The author believes that the failure to implement such a model over the last 34 years is due to the fact that possession and use continue to be dealt with in the criminal realm itself. A focus on criminal sanctions will always come at the expense of treatment.

However, with the release of the Issues Paper the greatest disappointment of all has been the Government's response. Although they are willing to listen to the submissions presented to the commission, the Minister of Justice, Mr Power, stated that "there's not a single, solitary chance that as long as I'm the Minister of Justice, we'll be relaxing drug laws in New Zealand". ${ }^{182}$

The determination of the Minister to stand by a legislative framework that is failing and issue such nonsensical statements is foolhardy. No evidence-based approach to drug policy can be generated on such absolutes. It is no flaw to change policy direction when the evidence warrants change, as John Maynard Keynes once quipped "when the facts change, I change my mind. What do you do, sir?"183

The evidence is clear. Change is needed. We now must decide on what change we want. It would be an injustice to allow the failed policies of yesterday to continue today. It is the author's strong recommendation that the Law Commission review its decision to exclude a model like Portugal's. If New Zealand wants treatment instead of sanction, fewer addicts rather than more and evidence-based policy rather than assumptions, we ought to implement a model similar to the one adopted in Portugal.

181 Board of Health Committee, above $\mathrm{n} 8$.

182 "Drug law proposals set to be rejected", above n 183.

183 Alfred L Malabre Lost Prophets: An Insider's History of the Modern Economists (Harvard Business School, Boston, 1994) at 220. 
APPENDIX 1: A COMPARISON - 1990 AND 1998 IN NEW ZEALAND

\begin{tabular}{lccccccc}
\multicolumn{7}{c}{ Relative usage levels of opiates, 1990 and 1998} \\
\hline \multicolumn{7}{c}{ tried } & \multicolumn{7}{c}{ tsed last year } & clurent user \\
& 1990 & 1998 & 1990 & 1998 & 1990 & 1998 \\
\hline Any opiates & $\%$ & $\%$ & $\%$ & $\%$ & $\%$ & $\%$ \\
Heroin & 3 & 4 & 0.7 & 1.3 & 0.5 & 0.6 \\
Homebake & 1.1 & 1.1 & 0.1 & 0.1 & 0.1 & 0.02 \\
Morphine & 0.7 & 1.2 & 0.3 & 0.5 & 0.1 & 0.3 \\
Poppies & 0.8 & 1.2 & 0.2 & 0.4 & 0.1 & 0.2 \\
Other opiates & 1.1 & 1.9 & 0.2 & 0.5 & 0.1 & 0.2 \\
(Percentages are of total sample) & 1.4 & 0.9 & 0.2 & 0.3 & 0.1 & 0.2 \\
\hline
\end{tabular}

Relative usage levels of other illegal drugs and intravenous use,

\begin{tabular}{lcccccc} 
& \multicolumn{3}{c}{1990 and 1998} \\
& \multicolumn{3}{c}{ tried } & \multicolumn{2}{c}{ used last year } & \multicolumn{2}{c}{ current user } \\
& 1990 & 1998 & 1990 & 1998 & 1990 & 1998 \\
& $\%$ & $\%$ & $\%$ & $\%$ & $\%$ & $\%$ \\
\hline Solvents & 0.9 & 1.8 & 0.2 & 0.3 & 0.1 & 0.1 \\
Tranquillisers & 1.8 & 2.1 & 0.6 & 0.4 & 0.3 & 0.4 \\
Intravenous use & 0.9 & 1.1 & 0.1 & 0.1 & 0 & 0.1 \\
\hline (Percentages are of total sample) & & & & \\
\hline
\end{tabular}

Percentage reporting use of any drug (excluding alcohol, tobacco and marijuana) in last 12 months, 1990 and 1998

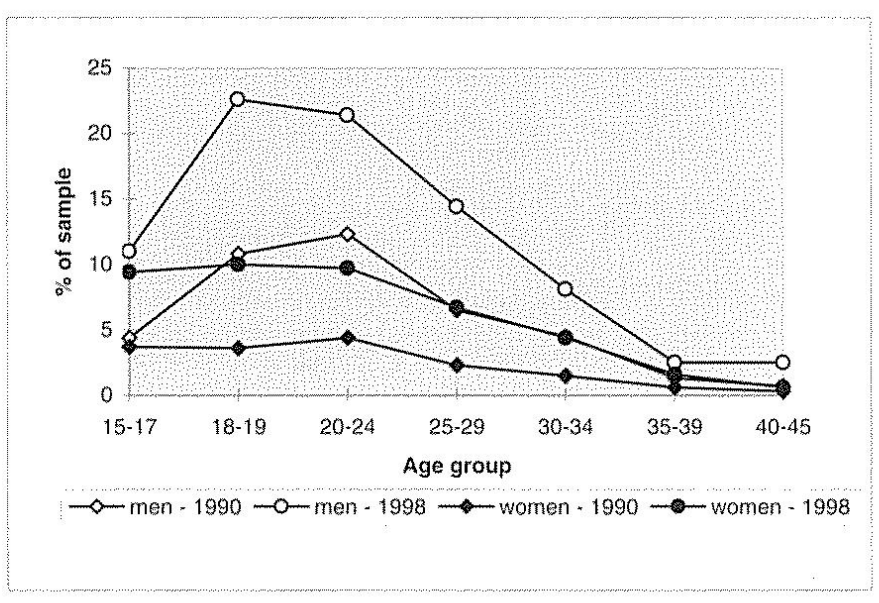


Source: Adrian Field, Sally Casswell Drug Use in New Zealand Comparison Surveys, 1990 \&1998 (Alcohol and Public Health Research Unit, Auckland University, 1999) at 39-45.

APPENDIX 1 CONTINUED: A COMPARISON-1998 AND 2001 IN NEW ZEALAND

\begin{tabular}{|c|c|c|c|c|c|c|}
\hline \multicolumn{7}{|c|}{ Relative usage levels of other illegal drugs and needles, $1998 \& 2001$} \\
\hline & \multicolumn{2}{|c|}{ Ever Tried } & \multicolumn{2}{|c|}{ Used Last Year } & \multicolumn{2}{|c|}{ Current User } \\
\hline & 1998 & 2001 & 1998 & 2001 & 1998 & 2001 \\
\hline & $\%$ & $\%$ & $\%$ & $\%$ & $\%$ & $\%$ \\
\hline Solvents & 19 & 22 & 04 & 02 & 02 & 0.1 \\
\hline Tranquilisers & 23 & 26 & 06 & 04 & 05 & 02 \\
\hline Intravenous use & 12 & 08 & 02 & 02 & 018 & 01 \\
\hline $\mathrm{GHB}$ & $\mathrm{n} / \mathrm{a}$ & 47 & $n / a$ & 08 & na & 03 \\
\hline Ketamine & 02 & 07 & 01 & 05 & 00 & 02 \\
\hline Rush & n/a & 47 & $n / a$ & 09 & nas & 0.5 \\
\hline Kava & 8,1 & 96 & 28 & 32 & 11 & 15 \\
\hline Other dnus & 07 & 09 & 02 & 02 & 0.1 & 0.1 \\
\hline
\end{tabular}

\begin{tabular}{|c|c|c|c|c|c|c|}
\hline \multicolumn{7}{|c|}{ Relative usage levels of opiates, $1998 \& 2001$} \\
\hline & \multicolumn{2}{|c|}{ Ever Tried } & \multicolumn{2}{|c|}{ Used Last Year } & \multicolumn{2}{|c|}{ Current User } \\
\hline & 1998 & 2001 & 1998 & 2001 & 1998 & 2001 \\
\hline & $\%$ & $\%$ & $\%$ & $\%$ & $\%$ & $\%$ \\
\hline Any oplates & 37 & 43 & 12 & 10 & 06 & 06 \\
\hline Herom & 09 & 07 & 02 & 0.1 & 01 & 003 \\
\hline Homebake & 12 & 15 & 06 & 0.5 & 02 & 03 \\
\hline Morphine & 11 & 10 & 0,4 & 02 & 02 & 0.06 \\
\hline Popples & 18 & 24 & 05 & 0,3 & 02 & 0,1 \\
\hline Other oprates & 08 & 10 & 03 & 03 & 01 & 01 \\
\hline
\end{tabular}

\begin{tabular}{lll} 
Relative usage levels of stimulants, 1998 \& 2001 \\
\hline
\end{tabular}




\begin{tabular}{|c|c|c|c|c|c|c|}
\hline \multicolumn{7}{|c|}{ Relative usage levels of hallucinogens, $1998 \& 2001$} \\
\hline & \multicolumn{2}{|c|}{ Ever Tried } & \multicolumn{2}{|c|}{ Used Last Year: } & \multicolumn{2}{|c|}{ Current User } \\
\hline & 1998 & 2001 & 1998 & 2001 & 1998 & 2001 \\
\hline & $\%$ & $\approx$ & $\%$ & $\%$ & $\%$ & $\%$ \\
\hline Any haluchogens & 128 & 150 & 55 & 61 & 36 & 43 \\
\hline$\angle S O$ & 88 & 96 & 38 & 32 & 28 & 20 \\
\hline Mushrooms & 76 & 89 & 22 & 24 & 12 & 18 \\
\hline Estasy (MDMA) & 30 & 54 & 15 & 34 & 10 & 23 \\
\hline Other halucinogens & 25 & 18 & 04 & 0.4 & 03 & 02 \\
\hline
\end{tabular}

Source: Alcohol and Public Health Research Unit Drug use in New Zealand National Survey Comparisons 1998 \& 2001 (Auckland 2002) <www.aphru.ac.nz> at 42-47. 
APPENDIX 2: A COMPARISON - 2001 AND 2006 IN PORTUGAL

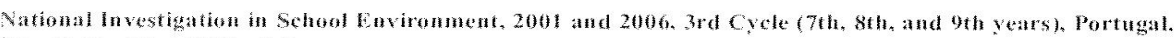
Prevalence Over Enetre Lite

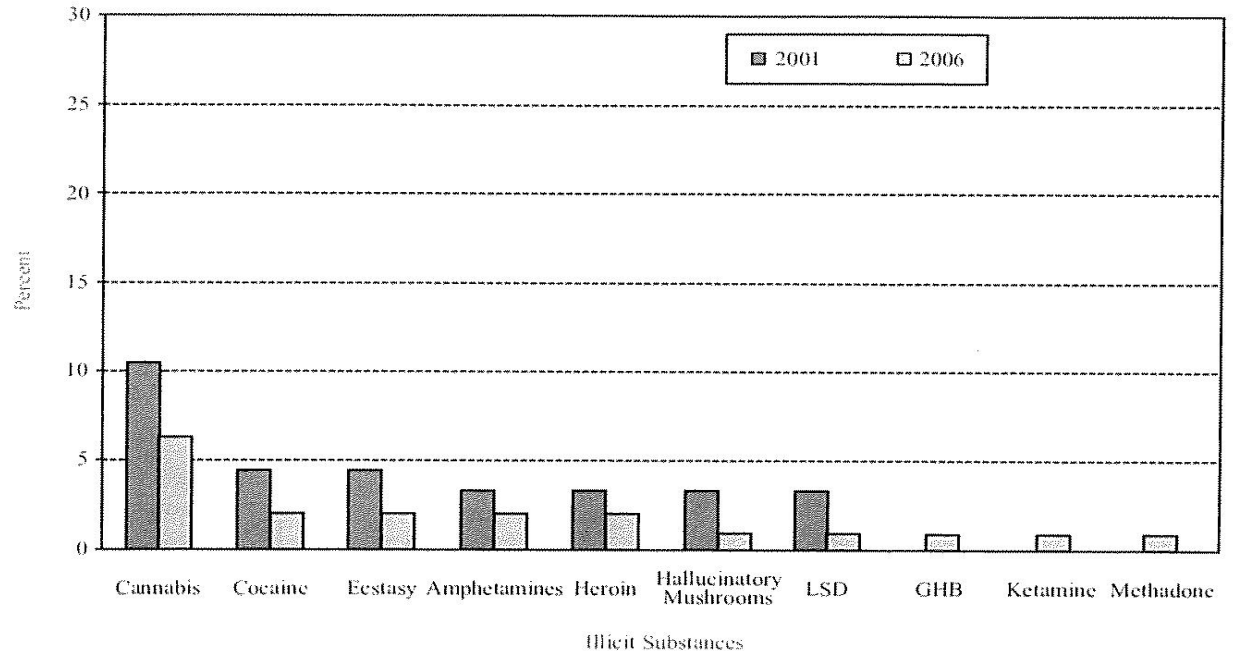

National Investigation in School Enviromment, 2001 and 2006 , Secondary (10th, 11 h, and 12 th years), Portugal. Prevalence Over Entire Life

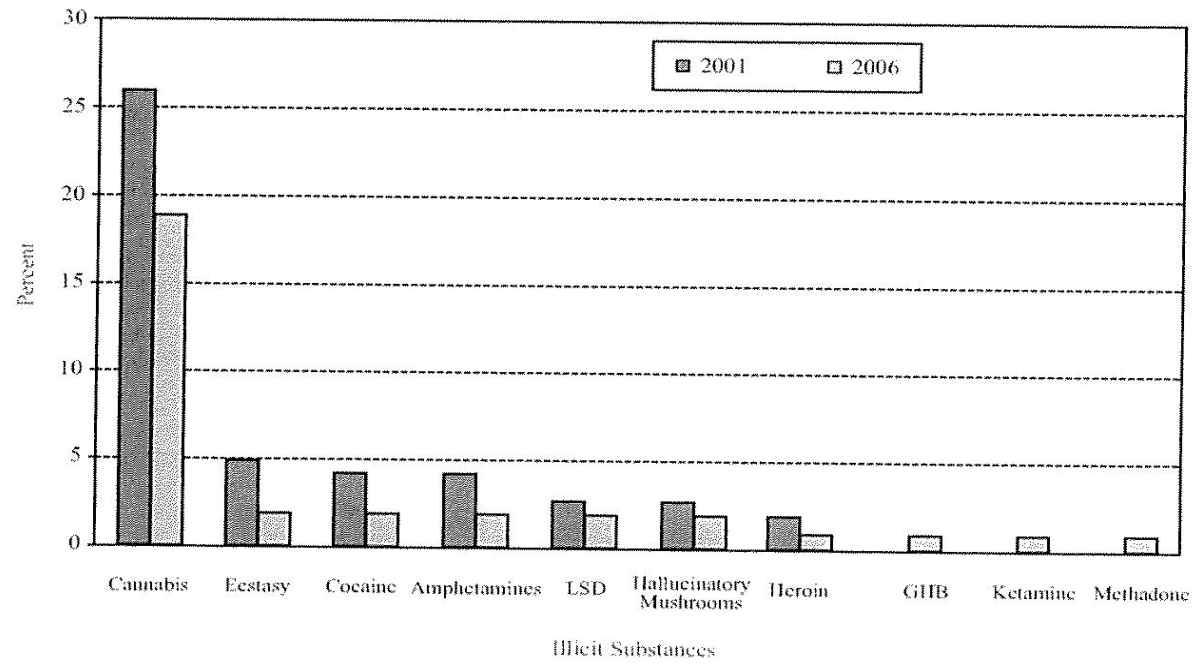


Source: Glenn Greenwald Drug Decriminalization in Portugal, Lessons for Creating Fair and Successful Drug Policies (CATO Institute, 2009) <www.cato.org>.

\section{APPENDIX 2 CONTINUED: A COMPARISON - 2001 AND 2006 IN} PORTUGAL

Figures

HIV/AIDS Notifiations, Pereent Drug Users and Nondrug Users by Vear of Diagnosis

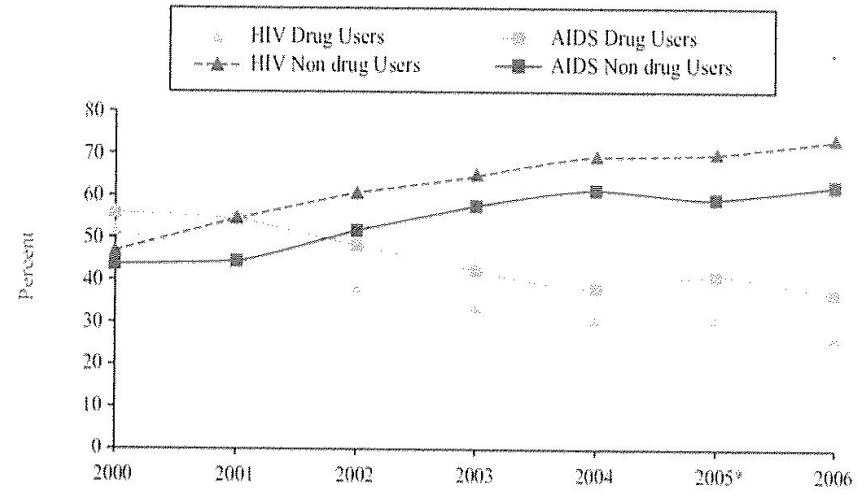

Source: Glenn Greenwald Drug Decriminalization in Portugal, Lessons for Creating Fair and Successful Drug Policies (CATO Institute, 2009) <www.cato.org>. 
